\title{
GEODETIC STUDIES WITH SIGNIFICANT CONTRIBUTION TO LANDSLIDE MONITORING IN SOUTH-WESTERN ROMANIA - AREA WITH HIGH RISK POTENTIAL
}

\author{
Clara-Beatrice Vilceanu, Ioan Sorin Herban, Carmen Grecea
}

Original scientific paper

This paper aims at presenting geodetic studies that are in close connection with landslide modelling and must be used for continuously monitoring the areas affected by geomorphological hazards. Although sometimes the geodesist's contribution to certain projects for landslide monitoring meant to develop early-warning-systems or risk maps is not adequately appreciated as stated in FIG Working Group (2006) [20] and he is only seen as supplier of measured geometric data, the geodesist has a significant contribution through his abilities regarding the modelling of dynamic systems, like strategic constructions (dams, tall buildings etc.) or landslides and data interpretation The study of how an objective affected by landslides behaves in time implies geodetic measurements performed at pre-set time intervals using state of the art technologies, which allow processing and review of data thus obtained in a three-dimensional system. Moreover, the goal is to set the stage for the shaping and optimization of monitoring networks by choosing the optimal research methods to be used.

Keywords: 3D modelling; digital terrain model; geodetic network; landslides; landslide monitoring; terrestrial laser scanning

\section{Geodetska istraživanja značajna za nadziranje odrona zemlje u jugo-zapadnoj Rumunjskoj - području visokog rizika}

Izvorni znanstveni članak Cilj rada je upoznavanje s geodetskim istraživanjima koja su usko povezana s modeliranjem odrona zemlje i moraju se primijeniti za trajno nadziranje područja u kojima dolazi do geomorfoloških opasnosti. Iako se ponekad nedovoljno cijeni doprinos geodeta nekim projektima za nadziranje odrona u svrhu razvoja sustava za rano upozorenje ili izradu karata s prikazom mogućih opasnosti, kako je navedeno u FIG radnoj grupi (2006) [20], i promatra ih se jedino kao dobavljače izmjerenih geometrijskih podataka, njihov je doprinos važan u modeliranju dinamičkih sustava, kao što su strateške konstrukcije (brane, visoke zgrade itd.) ili odroni zemlje te u interpretaciji podataka. Istraživanje ponašanja tijekom vremena nekog objekta zahvaćenog odronom uključuje geodetska mjerenja obavljena u ranije utvrđenim vremenskim intervalima primjenom najsuvremenijih tehnologija, koje omogućuju obradu pregled tako dobivenih podataka u trodimenzionalnom sustavu. Uz to, cilj je postaviti okvir za oblikovanje i optimizaciju mreža za nadziranje biranjem optimalnih istraživačkih metoda.

Ključne riječi: 3D modeliranje; digitalni model terena; geodetska mreža; nadziranje odrona zemlje; odroni zemlje; zemaljsko skeniranje laserom

\section{Introduction}

The specialists [1] drew attention to the fact that reducing hazard risk can be achieved through monitoring objectives, surfaces, regions or even the entire planet with the purpose of warning the population that could be affected by the hazard at the right time [21].

Recent studies [2] that have been conducted show that a very important role in hazard monitoring is played by geodetic technologies, namely GPS [3], remote sensing [4, 14], InSAR [5], LiDAR [6], TLS [15, 16], GIS $[17,7,8]$ due to their known advantages [9] in obtaining pertinent results related to 3D models of landslide affected areas and risk assessment.

Taking an overall view of the risk potential to landslides on the territory of Romania (Fig. 1), the necessity of studying these phenomena at regional level emerges, taking into account natural and anthropogenic factors in the area, to ensure the comfort of life, property that can be affected, planning space and land use, infrastructure upgrade, long-term resource management and adopt preventive measures for improving reactions to extreme natural phenomena.

The south-western region of Romania deals with instability phenomena, requiring timely detection of slide prone areas, in order to establish prevention methods and update the existing risk maps, issue also debated in [18], [22].

Landslides are not characteristic to the Mehedinţi County, but in recent years there have been many such phenomena due to heavy rainfall, massive deforestation and lack of banks and slopes along overall communication ways.

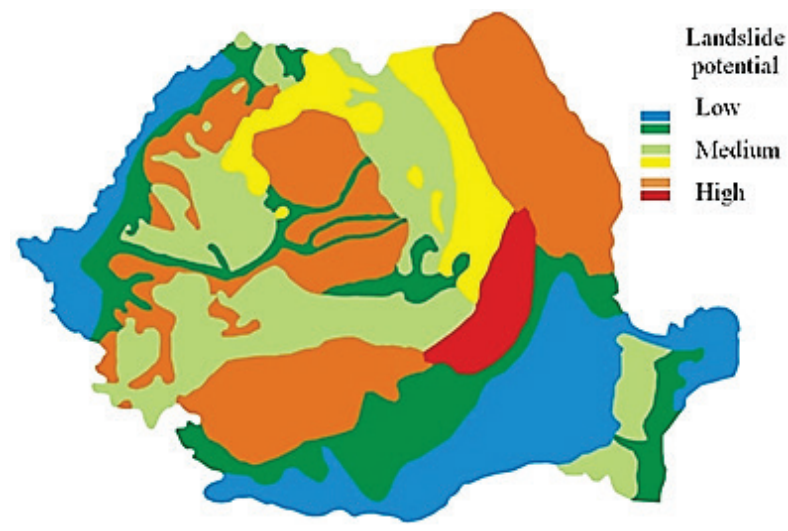

Figure 1 Romania - country with landslide potential [10]

The case study detailed in this paper aims to describe the methodology of monitoring the phenomenon of instability that has affected the access road to Aeolian plants of 3MW located on the Dranic peak in the Mehedinţi County by an overview of the geodetic measurements conducted. Current works include the processing of two sessions of geodetic measurements realized in order to determine the behaviour of the slope in time. The need for landslide monitoring is imposed by national legislation and policies of sustainable development.

What the present paper brings as innovation is that it proposes a work methodology that comprises complementary methods and technologies from the field of geotechnical and geodetic engineering that can be used for 
the evaluation and monitoring of landsliding risk generating processes. At the same time, the capabilities of programs specialized in 3D data processing [19] will be demonstrated, namely to generate real results when it comes to volumetric calculations.

Table 1 Level of the geotechnical risk for the road infrastructure

\begin{tabular}{|l|l|c|}
\hline \multicolumn{1}{|c|}{ Factors of influence } & $\begin{array}{l}\text { Characteristics of the } \\
\text { location }\end{array}$ & Points \\
\hline Soil conditions & $\begin{array}{l}\text { Sliding soils, and soils } \\
\text { with heaves and big } \\
\text { contractions }\end{array}$ & 6 \\
\hline Underground water & $\begin{array}{l}\text { With normal } \\
\text { dewatering }\end{array}$ & 2 \\
\hline $\begin{array}{l}\text { Classification of the } \\
\text { construction according to } \\
\text { the category of importance }\end{array}$ & Normal & 3 \\
\hline Neighbouring & Moderate risk & 14 \\
\hline TOTAL SCORE & & 3 \\
\hline
\end{tabular}

As a follow-up study to previous primarily field-based geotechnical studies by the authors [11] and according to the Romanian normative NP 074/2007 [23] entitled "Normative on the principles, exigencies and methods for the geotechnical research of the foundation ground", we have established the level of the geotechnical risk for the road infrastructure by combining some information on landslide phenomena and geologic conditions, as shown in Tab. 1.

One point is added to the total score obtained by the 4 factors and it corresponds to the calculus of the seismic area of the location. We obtain a total score of 15 points, which ranks the work in the "major" risk geotechnical category and from the geotechnical category point of view in category 3 .

\subsection{Description of the instability phenomenon}

In February 2011, at km 1+642 of the road situated in a road curve, a landslide was produced, having a width of $40 \mathrm{~m}$ and a length of $70 \mathrm{~m}$, downstream of the slope as illustrated in Fig. 2.

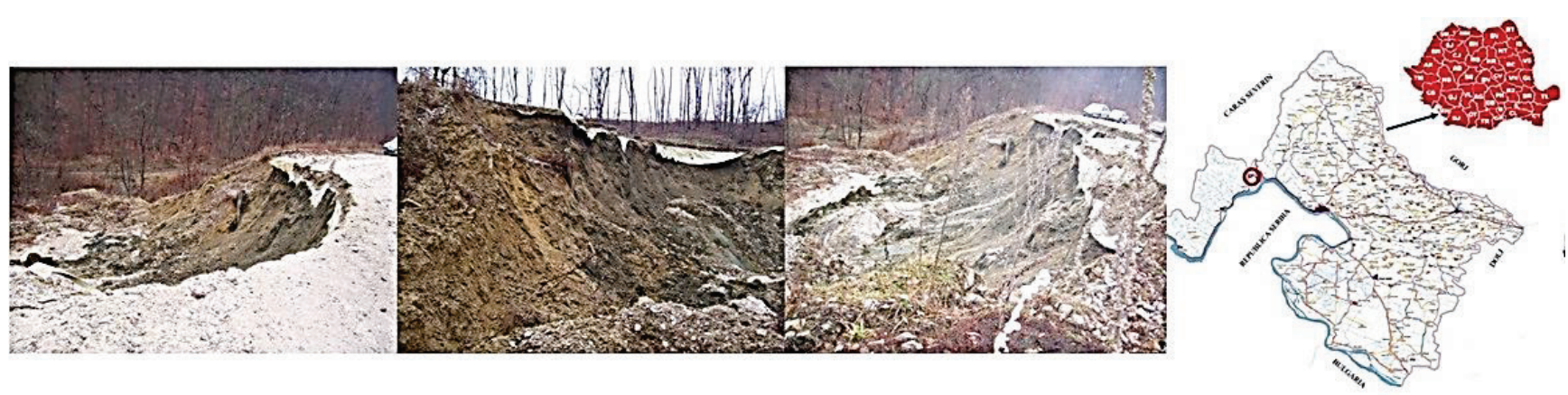

Figure 2 Geographical location of the studied area and the first landsliding in 2011

We have to consider the fact that Aeolian plants 3 MW were placed on the Dranic Peak (Dranic Slope), i.e. this implied the transport of the materials needed in order to make the foundations, the transport of the proper equipment, therefore the infrastructure as well as the superstructure of the technological road have been affected since they were not designed for heavy traffic.

The main factor that led to the instability of the roadway was the breakdown of the natural slope, from downstream up to the torrential valley placed at the foot of the slope, as a consequence of the excessive humidity of the area. Additional factors that led to the phenomenon were the following: the vibrations induced by the heavy traffic and the pressure exerted on the foundation soil.

\section{Materials and methods}

Geodetic methods as well as modern technology such as GPS [24] and TLS have been used for materializing a comparative study of digital terrain models of the area affected by the described landslide. The materials used to this objective are TCRA $1205+$ Total Station and the C10 Scanstation terrestrial laser scanner.

\subsection{Local geodetic support network}

In May 2012, after the field analysis and study of the existing materials, we created a support geodetic network which consisted in 7 points. The 4 geodetic height data
(GPS1, GPS4, GPS2, RGPS2) were materialized in the field under the form of reference marks type FENO (Fig. 3 ) which were placed on safe grounds. The distance ranges from $200 \div 300 \mathrm{~m}$ from the phenomenon observed in order to eliminate any possibility of being influenced.
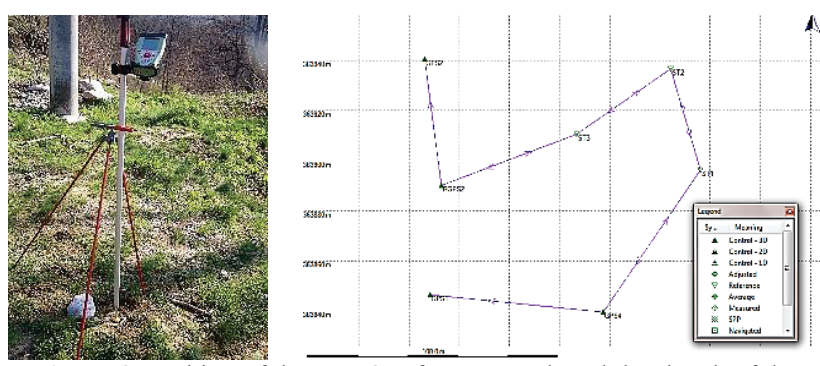

Figure 3 Marking of the FENO reference mark and the sketch of the geodetic support network

The point coordinates in the local geodetic support network were determined using GNSS technology, with the aid of the RTK Romanian Position Determination System service, by connecting to the Drobeta Turnu Severin permanent reference station inside the national GNSS permanent network stations (RN-SGP). The projected accuracy of the network points is according to the RTK service of the GNSS network of reference stations, namely smaller than $5 \mathrm{~cm}$. As regards the accuracy of the transformation parameters, it is given by the Romanian official projection system, 1970 Stereographic system. 
Leica Viva GS08 GNSS receiver (dual frequency) was used, having an accuracy for determining points RTK of $1 \div 2 \mathrm{~cm}$ and for postproccesing $6 \mathrm{~mm}(X, Y)$ and $9 \mathrm{~mm}$ $(H)$. According to the National Agency of Cadastre and Land Registration (NACLR) [25] and depending on the level of accuracy required for geodetic works, coordinates' transcalculating can be performed using TransDatRO software (standard deviation of conversion of $\pm 10 \div 15 \mathrm{~cm}$ ).

The sketch of the RTK network is presented in Fig. 4.

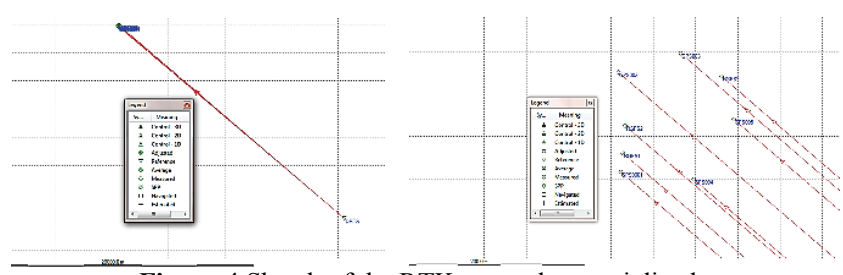

Figure 4 Sketch of the RTK network materialized

To assess the accuracy of the calculations, the error ellipses are highlighted for each traverse point and it is observed that the values of their semi-axes correspond to a class of very high precision - millimetre values, starting with $0,7 \mathrm{~mm}$, the maximum being 2,3 $\mathrm{mm}$ (Fig. 5) for the major semi-axis of the ellipse of ST1 traverse point.

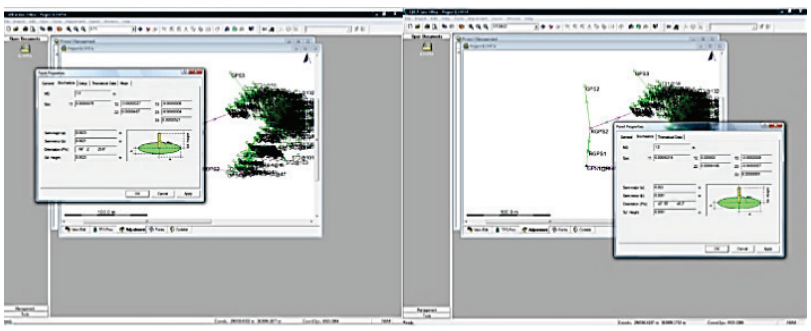

Figure 5 Error ellipses with their ampleness

The point coordinates are shown in Tab 2.

Table 2 The reference mark coordinates in the local geodetic support network - 2012

\begin{tabular}{|c|c|c|c|}
\hline Station & Easting $(\mathrm{m})$ & Northing $(\mathrm{m})$ & Height $(\mathrm{m})$ \\
\hline GPS4 & 296517,5931 & 363839,7123 & 131,1902 \\
\hline ST1 & 296555,6426 & 363896,1986 & 138,8403 \\
\hline ST2 & 296543,8275 & 363936,6568 & 145,4058 \\
\hline ST3 & 296506,3540 & 363910,4718 & 150,1728 \\
\hline RGPS2 & 296452,9216 & 363890,1311 & 156,3458 \\
\hline
\end{tabular}

Table 3 The reference mark coordinates in the local geodetic support network -2013

\begin{tabular}{|c|c|c|c|}
\hline Station & Easting $(\mathrm{m})$ & Northing $(\mathrm{m})$ & Height $(\mathrm{m})$ \\
\hline GPS4 & 296517,5918 & 363839,7145 & 131,1866 \\
\hline ST1 & 296555,6444 & 363896,1986 & 138,8301 \\
\hline ST2 & 296543,8280 & 363936,6588 & 145,4014 \\
\hline ST3 & 296506,3520 & 363910,4729 & 150,1645 \\
\hline RGPS2 & 296452,9220 & 363890,1338 & 156,3374 \\
\hline
\end{tabular}

Table 4 The horizontal and vertical displacements between $2012 \div 2013$

\begin{tabular}{|c|c|c|c|}
\hline Point & $\Delta y(\mathrm{~m})$ & $\Delta x(\mathrm{~m})$ & $\Delta h(\mathrm{~m})$ \\
\hline GPS4 & $-0,0013$ & 0,0022 & $-0,0036$ \\
\hline ST1 & 0,0018 & 0,0000 & $-0,0102$ \\
\hline ST2 & 0,0005 & 0,0020 & $-0,0044$ \\
\hline ST3 & $-0,0020$ & 0,0011 & $-0,0083$ \\
\hline RGPS2 & 0,0004 & 0,0027 & $-0,0084$ \\
\hline
\end{tabular}

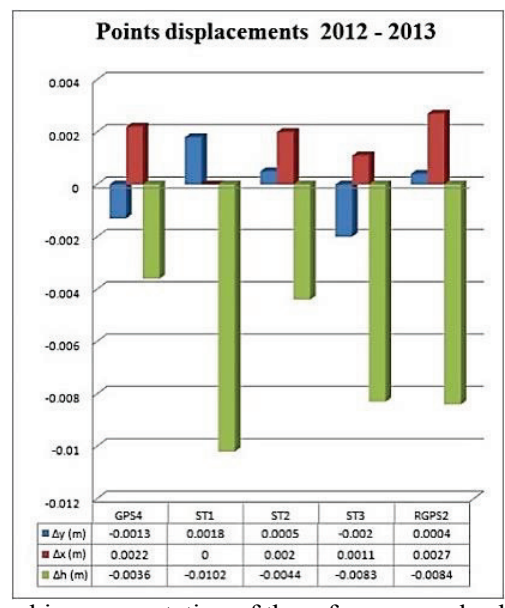

Figure 6 Graphic representation of the reference marks displacements

In 2013, the point coordinates in the local geodetic support network were determined again (Tab. 3) in order to establish both the compaction and the displacements of these reference marks (Tab. 4) illustrated in Fig. 6.

\subsection{Post processing of the measurements}

In order to obtain the digital terrain model, the measurements must have a tridimensional character. The survey was realized using Leica TCRA 1205+Total Station and the adjustment has been made into a network constrained on the starting points. The points on the body of the landslide have been collected into a network of quadrilateral figures with $2 \mathrm{~m}$ side to uniformly cover the studied phenomenon and accurately describe the ampleness of the landslide.

Very often new points describe in a suggestive manner natural land's configuration. In areas with pronounced deformations, new points were measured more often to create the 3D model with high precision. The measurements realized have been cyclic, considering as "0 cycle" the survey when the network was materialized, and in the subsequent cycles stabilization of the slope was observed, both from topographic measurements and visually (no cracks appeared in the road).

After performing and processing the measurements, files containing the planimetric coordinates of the points and their heights resulted. Then, these files have been imported into special software, Golden Surfer 9 and Civil 3D 2013, in order to create the DTM (digital terrain models) which may be useful for the calculus of thickness and volume of the landslide body; length and width of the landslide body; partitioning surface area by establishing directions of slip; determining the longitudinal and transverse sections etc.

\subsubsection{Civil 3D processing}

Post processing of the data started with the plotting of points on the orthophoto plan and then contour lines and 3D surfaces were created for both measurements campaigns as seen in Figs. 7, 8 and 9.

The cubic mass was calculated using TopoLT plugin for Civil 3D, M3D command. With the aid of this command, digital terrain models can be created based on 
points with $X, Y, Z$ coordinates or spatial lines and polylines.

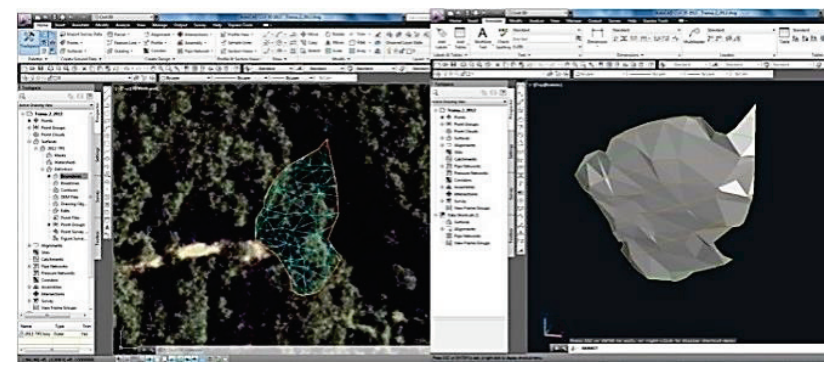

Figure 7 3D surface from 2012 measurements campaign

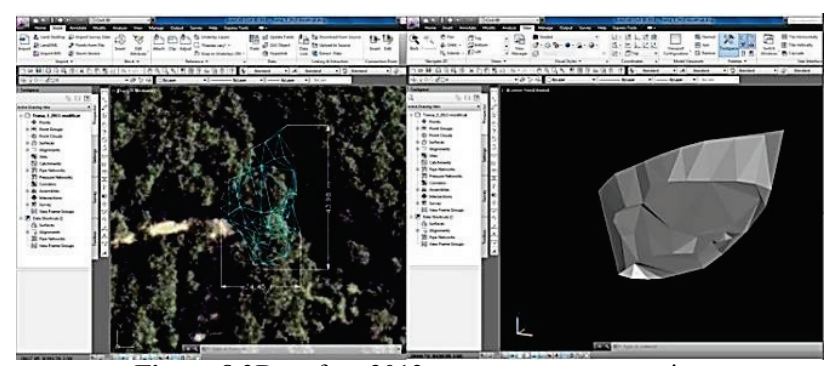

Figure 8 3D surface 2013 measurements campaign

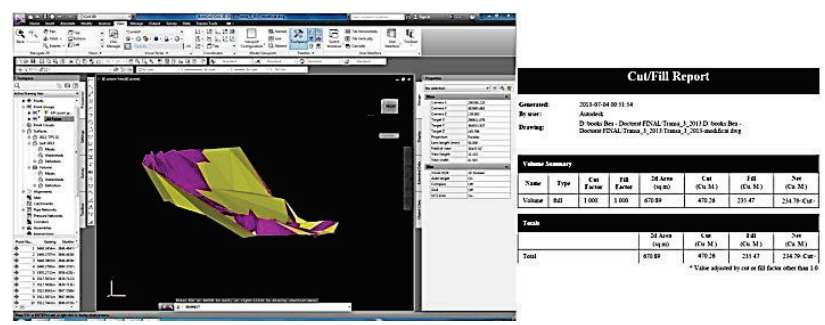

Figure 9 Overlapping of the $2012 \div 2013$ surfaces and the volumetric calculus

The final stage consisted in calculating the volume of the landslide to be able to compare it to the data obtained with the second program. Thus, we could identify which is best to be applied in the case of landslides and which provides the best results.

\subsection{Golden Surfer 9 processing}

The principle of processing the measured data is the same as the one previously described. The only difference is the fact that this programme implies the creation of some initial grids with the help of the coordinate files $X$, $Y, Z$ from the measurement campaigns of 2012 and 2013.

The contour lines for the studied area, schematic views of the created 3D object form and structure (Wireframes), shaded reliefs and the 3D models (Fig. 10) have at the basis the grids that have to have the same limits for each measurement campaign.

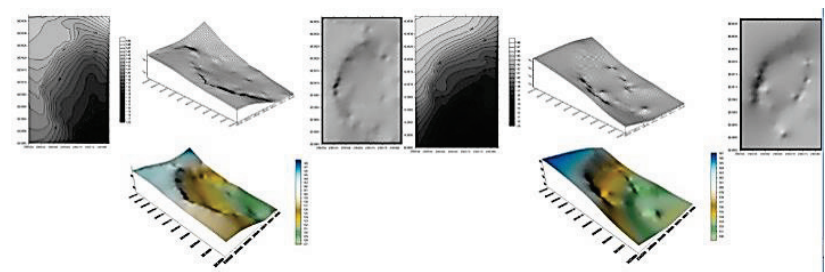

Figure 10 Digital terrain models of the area affected by landslides, from km 1+642 (on the technological road) between Orşova and the Topleț Plateau, Dranic peak, 2012 (on the left side) and 2013 (on the right side)
To be able to calculate the volume difference between the 2 measurement campaigns $(2012 \div 2013)$ we have to establish the interest perimeter. Out of the perimeter of interest we extract the coordinates $X, Y$ of the points which define the contour and we create a new coordinate file. We used programme Dxf2xyz 2.0. to be able to extract the point coordinates out of the file type .dwg which define the perimeter (Fig. 11).

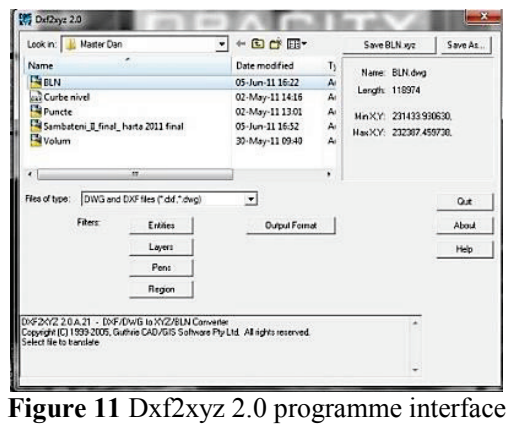

The coordinates obtained like this are introduced in the program Surfer 9, thus creating a new work sheet.

Above the first column we write the number of points that delimit the perimeter and which coordinates have been introduced.

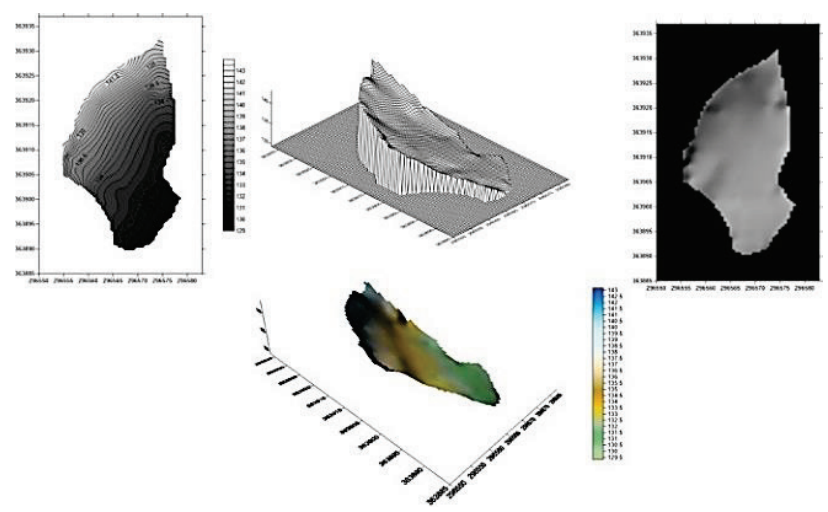

Figure 12 The 3D model of the interest zone - 2012 measurements campaign
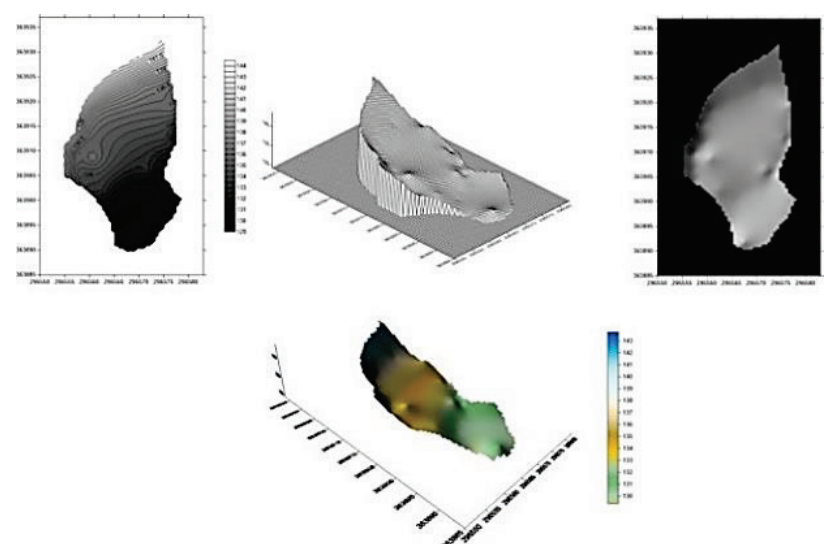

Figure 13 The 3D model of the interest zone - 2013 measurements campaign

Above the second column we write figure 0 , which signifies the interest zone. Figure 0 coincides with the interior of the perimeter and figure 1 with its exterior. Likewise, in order to suggest to the program a correct closing of our perimeter, the coordinates of the point 1 will have to be reintroduced at the end of the columns of 
the coordinates created. Then we have to save the modifications of the perimeter file, introduce a suggestive name, and choose the corresponding extension, i.e. .bln. Thus 3D models can be made of the interest area in the program (Fig. 12, 13).

Before starting the proper volumetric calculus shown in table 5 we overlap the grids created initially with the file of the perimeter obtained. Program Surfer 9 will then generate a report with the data on the volume of the existing earth in the interest area.

\subsection{Terrestrial Laser Scanning processing}

The scanning field campaigns have been performed at the same time with the topographic measurements effected with the total station that we have previously described.

The digital models of the scanned terrain (Fig. 14) were obtained following the use of a data filtering algorithm. This enables the point clouds to be separated from those points that are not relevant for creating the desired surface; operation that is possible by means of setting a rectangular network at equal distance specified by the user. Around the intersection points of the grid, the cylinders will be developed (automatically, by means of a program function), inside which the points with the lowest height will be searched. All points with the lowest height found inside the cylinders will be added to a Surface in Civil 3D, which actually represents the digital model of the terrain.
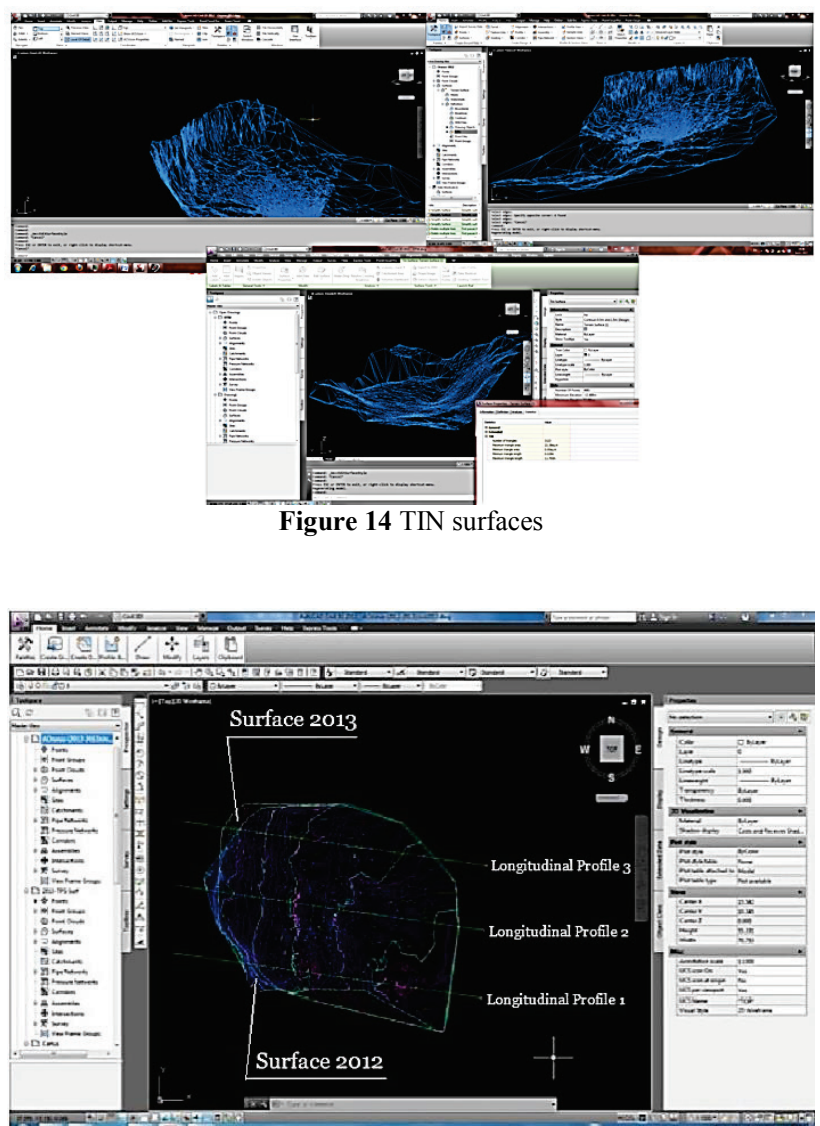

Figure 15 Overlapped 2012-2013 surfaces and directions for creating profiles
Fig. 15 illustrates both the overlapping of the two 3D surfaces created in order to determine the terrain's displacements and the producing of longitudinal profiles through the overlapped 3D surfaces needed for the highlighting of the landslide volume difference between the 2 measurement campaigns $(2012 \div 2013)$.

The next stage consisted in creating a new surface (Fig. 16), namely "Volume surface" which shows the settlings and is useful in the quantitative assessment of the landslide volume. After that, the interpretation of the obtained results becomes effortless, for example a visual analysis reveals the fact that the nature and the extent of the displacements were highlighted so one may easily perform a visual inspection in order to identify the landslides [24].

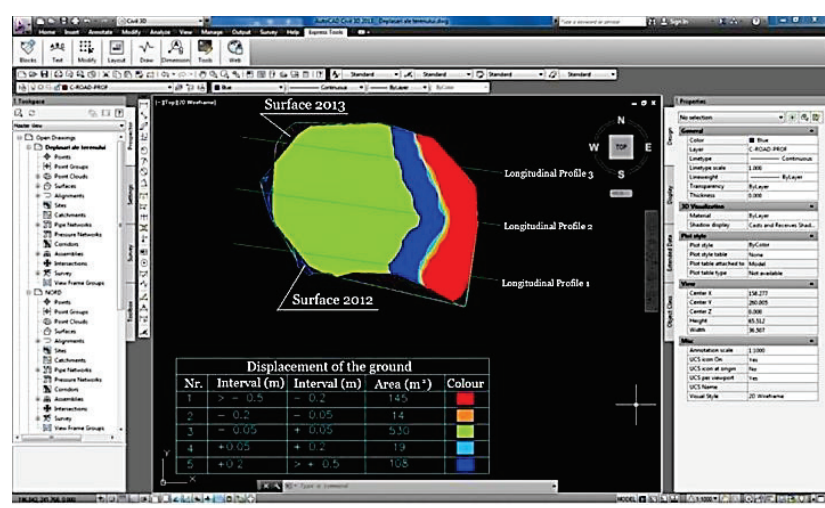

Figure 16 Terrain displacements

As it arises from Fig. 16, the most important displacements appear in the areas symbolised with red and orange colours. The red colour signifies the largest displacements contained in the interval $[-500 \mathrm{~mm},-200$ $\mathrm{mm}$ ] which are located at the upper part of the landslide and have affected the access road. The lower part of the slope was less affected, the displacements being situated in the interval $[-50 \mathrm{~mm},-2 \mathrm{~mm}]$.

\subsection{Analysis of the geodetic methods used}

For similar situations of landslides, on one hand, terrestrial photogrammetric method can be used when there is an opposite slope or field conditions allow data collection with this technique. On the other hand, methods specific to aerial photogrammetry (LiDAR or UAV) can be used, but in Romania the legislation is cumbersome and the process of obtaining approvals for the flight can take even a year. This makes this technique, with known advantages, such as being rapid and low-cost, inefficient. As regards LiDAR, the costs could be similar to using laser scan.

Regarding the interpolation methods for obtaining the 3D model, Civil 3D specialized software uses the Linear Interpolation with Triangulation, and the program Surfer, Krigging method. For each processing, the software calculates the standard error, coefficient of variation, skewness and Kurtosis. Obviously, one cannot compare two different interpolation methods, but the results obtained are close, so we conclude that the method of investigation and processing of the landslide proposed by the authors is correct. 
The mathematical model for determining cubic mass using Golden Surfer 9 is given by:

$$
R=\frac{\rho_{x y}}{\rho_{x} \times \rho_{y}},
$$

$$
\rho_{x y}=\sqrt{\frac{\sum_{i=1}^{n}\left(x_{i}-x_{\mathrm{med}}\right)\left(y_{i}-y_{\mathrm{med}}\right)}{n-1}},
$$

$\rho_{x}=\sqrt{\frac{\sum_{i=1}^{n}\left(x_{i}-x_{\mathrm{med}}\right)^{2}}{n-1}}$,

$$
\rho_{y}=\sqrt{\frac{\sum_{i=1}^{n}\left(y_{i}-y_{\text {med }}\right)^{2}}{n-1}} .
$$

$R$ represents the coefficient of multiple determination.

$R \in[-1 ;+1]$

$R^{2}=0,897657016535$.

\section{Results}

To study the landslides and to highlight their characteristics [25], a comparative study of the study results of modelling has been made with the help of the Program Surfer 9 and Civil 3D 2013 (Tab. 5).

Table 5 Volumetric calculus between the 3D models 2012-2013

\begin{tabular}{|c|c|c|c|}
\hline \multirow{2}{*}{ Criterion } & \multicolumn{2}{|c|}{$\begin{array}{c}\text { Total Station TCRA } \\
\text { 1205+ }\end{array}$} & $\begin{array}{c}\text { Scan station } \\
\text { C10 }\end{array}$ \\
\cline { 2 - 4 } & $\begin{array}{c}\text { Civil 3D } \\
2013\end{array}$ & Surfer 9 & $\begin{array}{c}\text { Civil 3D } \\
2013\end{array}$ \\
\hline $\begin{array}{c}\text { Volume of the } \\
\text { landslide }\end{array}$ & $470,26 \mathrm{~m}^{3}$ & $482,041 \mathrm{~m}^{3}$ & $477,530 \mathrm{~m}^{3}$ \\
\hline $\begin{array}{c}\text { Volume of the } \\
\text { filling }\end{array}$ & $235,47 \mathrm{~m}^{3}$ & $227,005 \mathrm{~m}^{3}$ & $228,270 \mathrm{~m}^{3}$ \\
\hline $\begin{array}{c}\text { Difference between } \\
\text { the landslide } \\
\text { volume - filling } \\
\text { volume }\end{array}$ & $234,79 \mathrm{~m}^{3}$ & $255,035 \mathrm{~m}^{3}$ & $249,260 \mathrm{~m}^{3}$ \\
\hline
\end{tabular}

Thus, for the study made on the access technological road, Dranic Peak - Orşova, it can be noticed that the Program Surfer has several advantages in comparison with Civil 3D:

- from the visual point of view the models made with the Program Surfer provide more information on the studied phenomenon to the specialist. On the 3D model obtained as a result of the measurements made in the year 2013 the ditches made by the meteoric water can be seen. Thus it can be easily concluded that the yielding by sliding of the land massif was caused by excessive humidity and by the fact that the meteoric water ponds at the foot of the slope and infiltrates itself in the land massive, transforming the dusty clay layers and the sandy clay layers into soft sliding soils;

- it does not require complex 3D modelling knowledge, since it has a friendly interface and suggestive commands;

- it allows the visualization of colour scale bars for a better understanding of the 3D model created, unless the drape option is used;

- it has a lower price.

\section{Discussion}

The landslide studied is of low depth, having a sliding plan situated at a distance of $-5 \mathrm{~m}$, and the displacement speed can be characterized as slow. As far as the sense of displacement is concerned it is of progressive type.

As far as the geodetic measurements are concerned we made a SWOT analysis of the obtained results.

As less favourable aspects we can mention some limitations. The initial idea was to make a digital model of the land affected by instability by digitalizing the level curves on the existing maps to be able to make a comparison between the 3 methods of obtaining these models. We found out that this type of processing is possible only if we have access to topographic plans at high scales, which also contain the level curves. More than this, the study area should be well represented, especially if it is of small dimensions, or, if the modelled zone is vast. Anyway, at this kind of study the precision of this type of processing would have been the lowest and the high costs could also have been a problem.

Even if the terrestrial laser scanning is not used on a wide scale for monitoring the surface of the earth crust within sciences that have it as a main point of interest, a significant number of scientists have proven the value of this technology for monitoring landslides and other hazards. The downside is that, after the analysis of the two three-dimensional models created, the 3D model resulted from the geodetic measurements was of inferior quality, although state-of-the-art technology was used.

As favourable aspects, we can mention:

- the use of modern geodetic technologies (both equipment and state of the art programs) offer significant benefits, such as: ability to measure the points situated in hard to access areas, minimizing the time needed to do the field measurements, complex and high precision results, pointing out the real evolution in time of a construction element or of the whole structure as an assembly, etc. However, the most important benefit is the obtaining of the 3D models of the terrain;

- the values of the compaction of the points in the local geodetic support network Orșova - Dranic Peak are low, i.e.: millimetres, the maximum compaction being recorded at the reference mark ST 1 situated near the landslide;

- the planimetric displacements determined for the points in the local geodetic support network are of millimetres, being situated in the admitted tolerance for this type of studies. 


\section{Conclusion}

In order to quantify the impact of landslides on the environment, one must identify the behaviour and then assess the consequences that they might have on the environment. One can say that this quantification is an analysis to determine how sensitive the sustainable development is when landslides occur.

The aim of quantification is to take measures to avoid slope sliding, which can be achieved by regular monitoring and by finding consolidation solutions.

It can be concluded that the breakdown by soil slip was caused by excessive humidity and by the fact that there is a coincidence between the geological slope of the earth layers and the slope of the natural slope of the hill.

The studies led to the conclusion that the stabilization of the access road towards the Aeolian aggregates can be made only by a complex road layer work that has to have the following:

- ditches to drain the water at the intersection of the 2 natural slopes which meet at the curve at $\mathrm{km} 1+642$; they would have the role to discharge the meteoric water and the water resulting from the snow thawing in the torrential valley at the foot of the hill;

- recompacting works for the land massif from the foot of the natural slope, with the area comprised between the line of the gabion positioning and the torrential valley at the foot of the slope. To make these works we think that large spalls should be used to be able to fill in the land in the area and the geogrid layers to reinforce the massif in the area, up to a minimum thickness of $2,00 \mathrm{~m}$.

From the point of view of landslide monitoring, we think that this paper highlights the importance of specialized geodetic research and situates it on a higher level in the hierarchy of environmental management and decision making process.

The processing and comparative interpretation of the terrain's digital models obtained by means of measuring campaigns performed at pre-set intervals offer precious information regarding the reason why landslides occur, the geomorphologic dynamics etc., with real value in the investigation and prognosis of such phenomena for relatively narrow areas. Grounded on these analyses, the following measures can be adopted by the local authorities in order to prevent a high landslide hazard: allot funds for landslide risk prevention, draw up monitoring programs with the purpose of developing early warning landslide systems, draw up emergency plans in case of landslide disaster, and set up programs to insure people and goods in the event of landslides. Last but not least to restrict or even prohibit the construction of buildings in the affected area and the changing of the land category.

\section{References}

[1] Li, D.; Shan, J.; Gong, J. Geospatial Technology for Earth Observation, Springer : New York, USA, ISBN 978-14419-0049-4, 2009, pp. 558. DOI: 10.1007/978-1-4419-0050-0

[2] Giardino, M.; Perotti, L.; Lanfranco, M.; Perrone, G. GIS and Geomatics for disaster management and emergency relief: a proactive response to natural hazards. // Applied Geomatics. 4(2012), pp. 33-46. DOI: 10.1007/s12518-0110071-z

[3] Liu, G.; Zhu, Y.; Zhou, R. A new approach of single epoch GPS positioning for landslide monitoring. // Acta Seismologica Sinica. 18, 4(2005), pp. 427-434. DOI: 10.1007/s11589-005-0020-1

[4] Canuti, P.; Casagli, N.; Ermini, L.; Fanti, R.; Farina, P. Landslide activity as a geoindicator in Italy: significance and new perspectives from remote sensing. // Environmental Geology. 45, (2004), pp. 907-919. DOl: 10.1007/s00254-003-0952-5

[5] Yin, Y.; Zheng, W.; Liu, Y.; Zhang, J.; Li, X. Integration of GPS with InSAR for the monitoring of the Jiaju landslide in Sichuan, China. // Landslides. 7, 3(2010), pp. 359-365. DOI: 10.1007/s10346-010-0225-9

[6] Ardizzone, F.; Cardinali, M.; Galli, M.; Guzzetti, F.; Reichenbach, P. Identification and mapping of recent rainfall-induced landslides using elevation data collected by airborne Lidar. // Natural Hazards and Earth System Science. 7, (2007), pp. 637-650. DOI: 10.5194/nhess-7-6372007

[7] Bălteanu, D.; Chendeș, V.; Sima, M. GIS landslide hazard map of Romania. // GIM International. 23, 4(2009).

[8] Mancini, F.; Ceppi, C.; Ritrovato, G. GIS and statistical analysis for landslide susceptibility mapping in the Daunia area, Italy. // Natural Hazards and Earth System Sciences. (2010), pp. 1851-1864. DOI: 10.5194/nhess-10-1851-2010

[9] Guglielmino, F.; Anzidei, M.; Briole, P.; Elias, P.; Puglisi, G. 3D displacement maps of the 2009 L'Aquila earthquake (Italy) by applying the SISTEM method to GPS and DInSAR data. // Terra Nova. 25, (2013), pp. 79-85. DOI: 10.1111/ter. 12008

[10] Bălteanu, D.; Chendeș, V.; Sima, M.; Enciu, P. A countrywide spatial assessment of landslide susceptibility in Romania. // Geomorphology. 124, 3-4(2010), pp. 102-112. DOI: 10.1016/j.geomorph.2010.03.005

[11] Vîlceanu, C. B.; Herban, S. I.; Muşat, C. C. Modern geodetic methods for monitoring landslides - Case study, The approach road between Orşova municipality and Topleț plateau, Dranic peak, Mehedinţi County. // Scientific Bulletin of The Politehnica University of Timişoara, Transactions on Hydrotechnics, ISSN 1224-6042, România, vol. 1, (2013), pp. 119-122.

[12] Herban, S.; Vîlceanu, C. B. Landslide monitoring in the context of sustainable development. // Research Journal of Agricultural Sciences. 44, 3(2012), pp. 213-221.

[13] Călarașu, E.; Dobrescu, C.; Siminea, I. The mechanism and the determining factors of producing the instability phenomena in the environmental impact assessment. // Annals. Food Science and Technology. 10, 2(2009), pp 543-548.

[14] Farina, P.; Moretti, S.; Colombo, D.; Fumagalli, A.; Manunta, P. Landslide Risk Analysis by means of Remote Sensing Techniques: Results from the ESA/SLAM Project. // Geoscience and Remote Sensing Symposium, IGARSS '04 Proceedings, IEEE International, ISBN: 0-7803-8742-2, (2004).

[15] Miller, P. E.; Mills, J. P.; Barr, S. L.; Lim, M.; Barber, D.; Parkin, G.; Clarke, B.; Glendinning, S.; Hall, J. Terrestrial Laser Scanning for assessing the risk of slope instability along transport corridors. // The International Archives of the Photogrammetry, Remote Sensing and Spatial Information Sciences. Vol. XXXVII. Part B5. Beijing, (2008).

[16] Sui, L.; Li, J.; Wang, X.; Zhao, D. Monitoring landslides dynamics using multitemporal terrestrial laser scanning data. // Second International Conference on Earth Observation for Global Changes, Proceedings of SPIE Vol. 7471, (2009). DOI: 10.1117/12.836335 
[17] Da Silva, F. P.; Rodrigues-Carvalho, J. A. Engineering geological mapping for the urban planning of Almada County, Portugal. // $10^{\text {th }}$ Congress International Association for Engineering Geology and the Environment, (2006).

[18] Manea, S.; Olinic, E. Ensuring slope stability during the execution of new constructions. // Proceedings of Landslide Risk Mitigation - Challenge and Strategy, Exploratory Workshop, Rotaru A. Editor, Politehnium Press, Iaşi, Romania, (2009).

[19] Didulescu, C.; Savu, A.; Badea, A. C.; Badea, G.; Bădescu, G. Modeling and Visualization Objects from Point Cloud Data Surveyed With Terrestrial Laser Scanner. // $3^{\text {rd }}$ WSEAS International Conference MEQAPS '11, ISBN 978-960-474-294-3, Romania, (2011), URL: http://www.wseas.us/books/2011/Brasov2/MEQAPS.pdf

[20] International Federation of Surveyors (FIG). Working Group 8.4, The Contribution of the Surveying Profession to Disaster Risk Management, Copenhagen, Denmark, 2006, pp. 16-26. URL: https://www.fig.net/pub/figpub/pub38/ figpub38.htm

[21] Intergovernmental Panel on Climate Change (IPCC), 2007. Climate change 2007: impacts, adaptation and vulnerability. In: Parry, M. L.; Canziani, O. F.; Palutikof, J. P.; van der Linden, P. J. \& Hanson, C. E. eds. Contribution group II to the fourth assessment report of the intergovernmental panel on climate change. Cambridge, UK: Cambridge University Press, URL: http://www.ipcc.ch/pdf/assessment-report/ar4/wg2/ar4_ wg2_full_report.pdf

[22] Stoian, I.; Olaru, V.; Baroiu, N. Making Landslides Risk Maps as Monitoring Systems of the Phenomenon Based on Precision Geodesic Measurements. // FIG Working Week Bridging the Gap between Cultures, Marrakech, Morocco, (2011), URL: http://www.fig.net/pub/fig2011/papers/ ts09e/ts09e_stoian_olaru_et_al_5160.pdf

[23] Standard NP 074 regarding geotechnical specification for civil engineering, Romania, (2007). URL: http://webcache.googleusercontent.com/search?q=cache:htt p://www.mdrt.ro/userfiles/consultari_publice/24_04_13/act 12.doc

[24] Manetti, L.; Knecht, A.; Frapolli, M.; Lou, H. Integrating GPS and Laser Distance Meters for landslide monitoring, European Geophysical Society. // XXVII General Assembly, Nice, France, (2002), URL: http://www.roctestgroup.com/sites/default/files/bibliography/pdf/c181.pdf

[25] http://www.ancpi.ro/pages/wiki.php?lang=ro\&pnu=transfor mariCoordonate

\section{Authors' addresses}

Clara-Beatrice Vilceanu, Assistant Professor PhD.

Politehnica University Timişoara, Faculty of Civil Engineering, Department of Overland Communication Ways, Foundations and Cadastral Survey, Traian Lalescu 2 Str., room 206, Timisoara Tel/Fax: +40 256 403983/+40 256404010

E-mail: beatrice.vilceanu@upt.ro

\section{Ioan Sorin Herban, Associate Professor PhD.}

Politehnica University Timişoara, Faculty of Civil Engineering, Department of Overland Communication Ways, Foundations and Cadastral Survey, Traian Lalescu 2 Str., room 209, Timisoara Tel/Fax: +40 256 403982/+40 256404010

E-mail: sorin.herban@upt.ro

Carmen Grecea, Professor PhD.

Politehnica University Timişoara, Faculty of Civil Engineering, Department of Overland Communication Ways, Foundations and Cadastral Survey, Traian Lalescu 2 Str., room 205, Timisoara Tel/Fax: +40 256 403982/+40 256404010

E-mail: carmen.grecea@upt.ro 